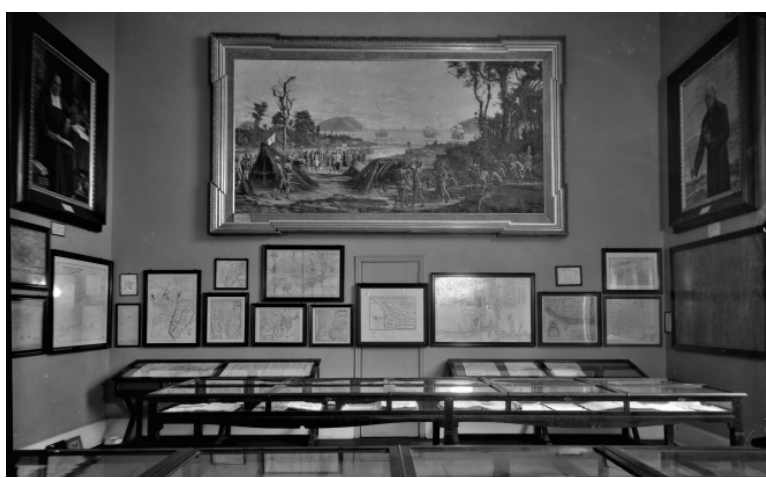

*Mestre em Museologia pelo Programa de Pós-Graduação Interunidades em Museologia da Universidade de São Paulo (2016-2018), onde desenvolveu a pesquisa "Fundação de São Vicente, de Benedito Calixto: composição, musea- lização e apropriação (19001932)", sob orientação do Prof. Dr. Paulo César Garcez Marins, com financiamento da Fundação de Amparo à Pesquisa do Estado de São Paulo e estágio na Université Paris I Panthéon-Sorbonne.

\title{
Fundação de São Vicente, a(s) biografia(s) de uma pintura (1892-1939)
}

\author{
Fundação de São Vicente, a painting biography (or biographies) (1892-1939)
}

Eduardo Polidori Villa Nova de Oliveira*

\section{Resumo}

Este artigo propõe reconstituir as múltiplas apropriações que marcaram a trajetória da tela "Fundação de São Vicente", de Benedito Calixto, que pertence ao acervo do Museu Paulista desde 1900. Para tanto, apresentam-se as condições de sua produção e inauguração durante o $4^{\circ}$ Centenário do Descobrimento do Brasil, os usos políticos da pintura pela Sociedade Commemoradora, o processo de sua aquisição definitiva pelo governo paulista e como a pintura foi exibida durante as gestões de Hermann von Ihering (1894-1916) e de Afonso Taunay (19171946) no Museu Paulista, mobilizando exemplos que demonstram como o museu público agencia e difunde concepções político-imaginárias a partir das pinturas históricas.

Palavras-chave: Benedito Calixto. Museu Paulista. Pintura Histórica.

\section{Abstract}

This paper proposes to reconstruct the multiple appropriations that marked the trajectory of the history painting "Fundação de São Vicente" by Benedito Calixto, which belongs to the Museu Paulista collection since 1900. To achieve this goal, it will be presented the conditions of its production and inauguration during the 4th Centenary of the Discovery of Brazil, its political uses by the commemorative association; the process of the painting definitive acquisition by the government of the State of São Paulo and finally how it was exhibited during Hermann von Ihering's (1894-1916) and Afonso Taunay's (1917-1946) administration periods in the Museu Paulista, mobilizing some examples which can demonstrate how public museums diffuses political-imaginary conceptions from their history paintings.

Keywords: Benedito Calixto. Museu Paulista. History Painting. 
1. Refiro-me, por exemplo, ao livro Villa de Itanhaém, de 1895, e a Capitanias paulistas, de 1915. Sobre a carreira de Benedito Calixto como artista e intelectual, cf. ALVES, C. F. Benedito Calixto e a construção do imaginário republicano. Bauru: EDUSC, 2003.

2. Correio Paulistano, $27 \mathrm{de}$ maio de 1883, p. 01: (...) $O$ exm. sr. visconde de Vergueiro dignou-se visitar o intelligentissimo moço, subindo a seus aposentos examinou alguns trabalhos concluidos (...) Depois convidou-o á ir almoçar com elle d'ahi a dias, e a levar nessa occasião os trabalhos concluidos para serem examinados pelo nosso Victor Meirelles, e apresental-o também a este nosso patrício afim de que elle, como mestre, desse igualmente sua autorisada opinião a respeito. (...)".

3. Atelier de MM. Boulanger et J. Lefebvre, Fonds de l'Académie Julian (18701932), Archives Nationales, Pierrefitte-sur-Seine, França.
I.

Benedicto Calixto de Jesus nasceu em Itanhaém, litoral paulista, em 1853. As suas contribuições como pintor e historiador são marcas indeléveis do patrimônio cultural do Estado de São Paulo: nos museus, nas decorações de igrejas da capital e do interior, nas coleções privadas e, não menos importante, na historiografia das primeiras duas décadas do século XX, quando publicava ativamente sobre temas diversos a respeito da história vicentina e paulista ${ }^{1}$.

Por convite de Manuel Garcia Redondo, Calixto trabalhou na decoração interna do Theatro Guarany. Tendo seu trabalho apreciado e reconhecido, foi recomendado para o visconde Nicolau José de Campos Vergueiro, que lhe ofereceu custear seus estudos em Paris. Foi assim que, entre 1883 e 1884, teve contato com o efervescente cenário artístico da capital francesa, tornando-se, inclusive, um assíduo frequentador do Mu- seu do Louvre, do Museu Nacional de Versalhes e das igrejas de Notre-Dame e Sainte Chapelle. (ALVES, 2003, p. 90)

Reporta um jornal da época que o visconde de Vergueiro acompanhou de perto os estudos e avanços de Calixto $^{2}$, antes no ateliê de Jean-François Rafaëlli e, logo a seguir,na Académie Julian, matriculando-se no ateliê dirigido por Jules Lefébvre (1834-1912) e Gustave Boulanger (1824-1888), recebendo ali sua formação como pintor ${ }^{3}$.

Além do custeio dos estudos, Vergueiro lhe apresentou a Victor Meirelles, então professor da Academia Imperial de Belas Artes e que, nessa ocasião, fora a Paris para exibir a segunda versão do "Combate Naval de Riachuelo" (óleo sobre tela, 420 x $800 \mathrm{~cm}, 1883$ ) no Salon de 1883. A partir desse encontro, tomaria Meirelles, o autor 
da obra "Primeira Missa no Brasil" (óleo sobre tela, $268 \times 356 \mathrm{~cm}, 1860$ ) como referência sólida em seu horizonte ${ }^{4}$.

Mas, em 1881, dois anos antes de embarcar para a França, Calixto elaborava e inaugurava duas pequenas telas a óleo com temática histórica: "Porto das Naus" $(50 \times 75 \mathrm{~cm})$ e "Desembarque de Martim Affonso de Souza" (47 x $73 \mathrm{~cm}$ ), representando as cenas imediatamente anteriores à fundação da capitania vicentina, em 1532.

O contato com as coleções de antiguidades do Museu do Louvre despertaram em Calixto interesse suficiente para que, retornando ao Brasil em agosto de 1884, tivesse o ímpeto de ampliá-lo para a história colonial vicentina - assunto pelo qual já sinalizava querer aproximar-se, como documentam as pinturas mencionadas acima ${ }^{5}$. Por isso que, ainda em 1888, aproximou-se dos arquivos Convento de Itanhaém. A pesquisa extensa e minuciosa dos documentos, cuja descrição era sempre detalhada e precisa, alicerçou a escrita de Villa de Itanhaem, primeira contribuição historiográfica do pintor, publicada em 1895.

A primeira parte do livro é dedicada a explorar e discutir, especialmente a partir das obras do historiador e brigadeiro José Joaquim Machado de Oliveira e de Gaspar da Madre de Deus, cronista e frei beneditino, a fundação das vilas de São Vicente, de Santo André da Borda do Campo, de São Paulo de Piratininga, de Santos e de
Itanhaém ${ }^{6}$. Essa preocupação de Calixto, no entanto, não se explica apenas por uma ânsia de erudição, mas, sobretudo, como uma forma de se afirmar simbolicamente como intelectual e, no limite, autoridade sobre a história local.

Calixto não se furtou em divulgar esse trabalho: o agradecimento que consta logo na primeira página revela os seus esforços em consolidar sua inserção, enviando o livro ao jurista e intelectual ultramontano João Mendes de Almeida (18311898) e ao diretor da Repartição de Estatística e Arquivo do Estado de São Paulo, Antônio de Toledo Piza e Almeida (1848-1905), também responsável por organizar a publicação oficial dos documentos históricos pelo governo, além de ser membro ativo do Instituto Histórico e Geográfico paulista desde novembro de 1894.

Somada a produção historiográfica a respeito das fundações quinhentistas em São Paulo, Calixto elaborava outro plano desde, pelo menos, 1892. No contexto da república nascente e marcada pela necessidade de afirmação simbólica perpetrada pela elite perrepista, a fundação de instituições voltadas à produção e universalização do conhecimento - a Escola Normal, o Instituto Histórico e Geográfico e, sobretudo, o Museu Paulista -, o pintor encontrou uma solução para se consolidar como agente da fabricação simbólica em curso e, ao mesmo tempo, exaltar e rememorar a participação das cidades sul-litorâneas na formação do território paulista: a fundação da 
7. Cf. NEVES, Cylaine Maria das. A Vila de São Paulo de Piratininga. Fundação e Representação. São Paulo: Annablume; FAPESP, 2007; FERREIRA, Antônio C. A epopeia bandeirante: letrados, instituições, invenção histórica (1870-1940). São Paulo: Editora UNESP, 2002; FERRETTI, Danilo José Zion. A Construção da Paulistanidade: identidade, historiografia e política em São Paulo (1856-1930). Tese (Doutorado em História Social) Universidade de São Paulo, São Paulo, 2004.

8. PINHEIRO, José Feliciano Fernandes. Anais da província de São Pedro do Rio Grande do Sul. Rio de Janeiro: Imprensa Nacional, 1839. p. 31.

9. THUILLIER, Jacques. Le problème des 'grands formats'. IN: Revue de l'Art, $\mathrm{n}$. 102, 1993.

10. A "Sociedade Commemoradora do $4^{\circ}$ Centenario da Descoberta do Brazil" foi a associação particular formada para organizar as comemorações vicentinas do Descobrimento e reunia em seu quadro a elite política e comercial das cidades de Santos e São Vicente e, especialmente, a entourage do senador estadual José Cesário da Silva Bastos, da família dos proprietários do Cidade de Santos, periódico de circulação diária fundado em 29 de agosto de 1898 Bastos liderava o Partido Republicano Paulista em Santos, tendo ocupado a cadeira senatorial paulista na década de 1890. Outro membro proeminente era o farmacêutico José Ignácio da Glória, também empresário da imprensa e que fundou, em setembro de 1899 o hebdomadário Vicentino. Caberia ainda mencionar o protagonismo de Gregório Inocêncio de Freitas: político tradicional, ele foi aclamado presidente da associação presidia a Câmara Municipa de $\mathrm{S}$. Vicente à época, além de ser comissário de café em Santos.

11. O Estado de S. Paulo, 08 de abril de 1899, p. 01. capitania de São Vicente por Martim Afonso de Souza, em $1532^{7}$

Com isso, além de exaltar a participação de São Paulo na formação do Brasil em um momento de reconfiguração política, recobrava um topos historiográfico difundido pelo visconde de São Leopoldo no contexto inicial do Instituto Histórico e Geográfico Brasileiro (do qual havia sido membro-fundador), e que escrevia que a "história de São Paulo era a história do Brasil."8

Em 1892, Calixto recebeu uma carta elogiosa de Victor Meirelles sobre o plano composicional que havia pensado para representar o episódio vicentino: Meirelles lhe anexou um esquisse que ilustrava suas sugestões, tendo sido seguidas por Calixto com alguma precisão. Embora não pudesse ter uma séance de correction usual, como presenciara na escola parisiense, Calixto à autoridade representada pelo professor da AIBA para validar o projeto da pintura histórica que elaborava e que viria a ser, anos depois sua primeira pintura histórica em grande formato.

Mesmo que tenha planejado cuidadosamente a composição, alicerçando o pincel em livros e documentos, não foi feliz em obter os recursos necessários para subsidiar a pintura e, tampouco, parece ter se esforçado em viabilizá-la por encomenda particular. É compreensível, uma vez que, recobrando Jacques Thuillier, os destinos das composições em grande formato eram os gran- des edifícios da administração pública ou, em que pese a tradição francesa oitocentista como paradigma - os museus de História9 ${ }^{\text {. }}$

Para que pudesse negociar estrategicamente a inauguração da pintura, Calixto foi obrigado a esperar quase uma década, quando foram iniciados os preparativos para o $4^{\circ}$ Centenário do Descobrimento do Brasil na pequena São Vicente. É isso que veremos a seguir.

\section{II.}

Organizada pela "Sociedade Commemoradora do IV Centenario da Descoberta do Brazil"10, as comemorações previam a inauguração de um monumento público no Largo 13 de Maio (atualmente, Praça 22 de Janeiro), uma exposição arqueológica e artística, uma exposição de fotografias do litoral e de outras localidades do Estado de São Paulo e festas populares noturnas.

Nos Estatutos não está enunciada a intenção de encomendar uma pintura por parte da associação. Em 08 de abril de 1899, a Commemoradora se ocupou em exortar os paulistas a compartiIharem seu esforço em comemorar a história paulista, solicitando que fossem enviados recursos financeiros para cumprimento dos objetivos acima mencionados e, em se somando àqueles, para a encomenda de um "panorama histórico representando a fundação da capitania de São Vicente". 
Calixto acordou a venda da obra por dez contos de réis, mas sua contrapartida ia muito além da entrega da pintura, sendo o responsável pela concepção da identidade visual da Commemoradora (e.g., timbre para papel de carta) e por decorar os salões e as vias públicas que eventualmente recebessem eventos oficiais ${ }^{12}$.
$\mathrm{Na}$ tarde de 20 de abril de 1900, testemunhada pelas autoridades de Santos e São Vicente, pela imprensa e pelos representantes da Commemoradora, a "Fundação de São Vicente" fora inaugurada na abertura da "Exposição Historica e Archeologica", ocasião que, por sua vez, dava início à programação comemorativa do Descobrimento do Brasil. (Figura 1).
12. Cidade de Santos, $21 \mathrm{de}$ abril de 1900, p. 01.

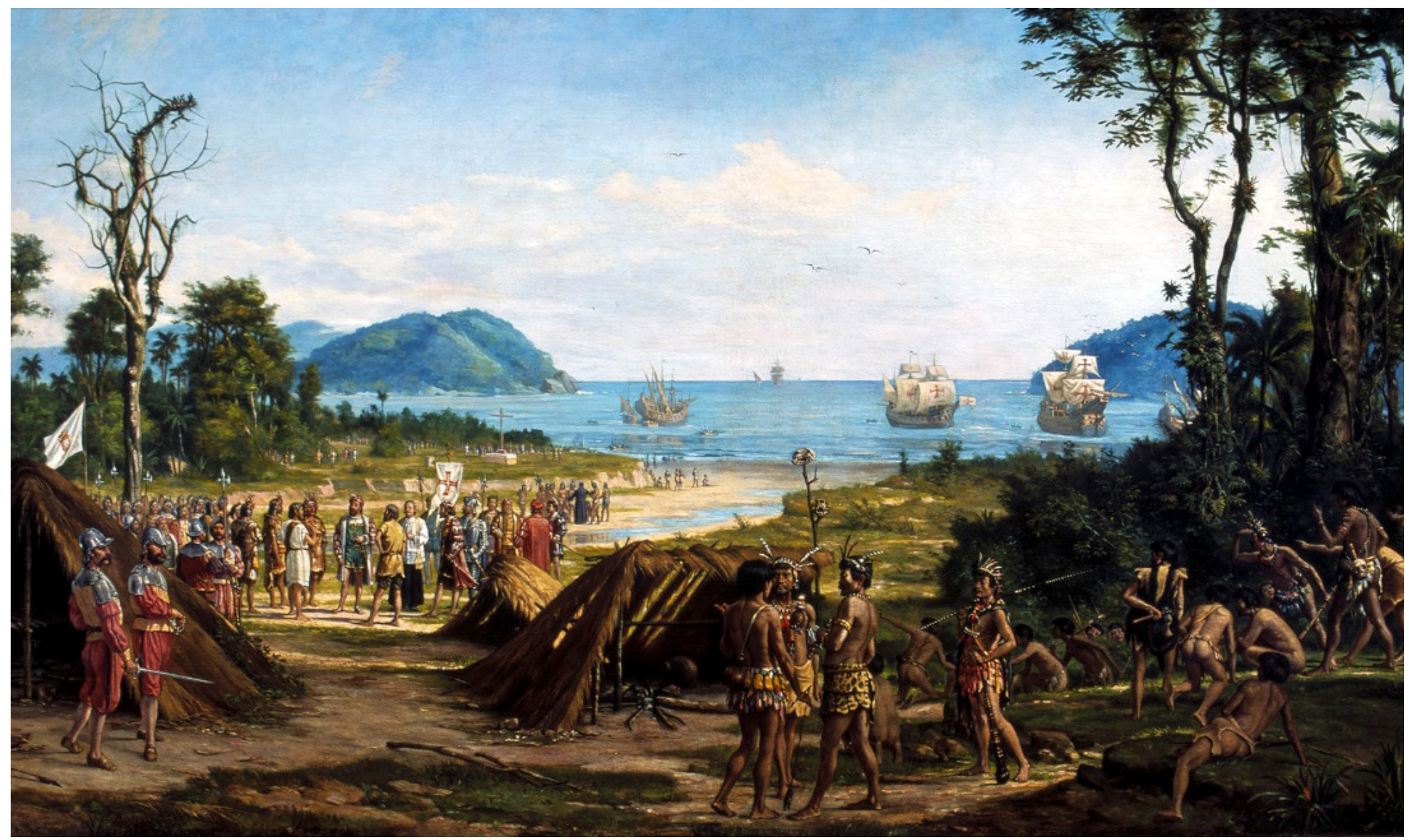

Figura 1. "Fundação de São Vicente" (óleo sobre tela, 385 x 192 cm, 1900), de Benedito Calixto. Acervo do Museu Paulista da USP. 
13. Em 1900, a Fratelli Secchi já completava quatro anos de atividades, sendo uma das quatro fábricas de alimentos fundadas por imigrantes italianos durante a década de 1890 em São Paulo. Cf. CENNI, Franco. Italianos no Brasil. 3. ed. (1. ed. 1960) São Paulo: Edusp, 2003, p. 256-257.

14. Cidade de Santos, 21 de abril de 1900, p. 02

15. Cidade de Santos, 21 de abril de 1900, p. 02.

16. Vicentino, 03 de abril de 1900, p. 01: “(...) Por instincto, amantes das artes, e por princípios dedicados á industria, que consideramos como um dos principaes mananciaes do bem estar do povo e como um grande incentivo para o progresso moral, nos occuparemos sempre que for possivel, do progresso das artes, por meio da imprensa, único conductor mais apropriado de que dispomos. Julgamos occazião oportuna appelar-mos para os cultores das artes e os operários para nos auxiliarem com o seu concurso em prol da exposição que vae installar no edifício da Escola do Povo nesta cidade."

17. Refiro-me à "Inundação da Várzea do Carmo" (óleo sobre tela, $400 \times 125 \mathrm{~cm}$, $1892)$, adquirida pelo governo do Estado em 1892.
No dia seguinte, a exposição foi aberta à visitação pública. A pintura estava na primeira sala, conjuntamente a objetos que, a primeira vista, destoavam de uma pintura histórica: um "matador de formigas" inventado por Dr. Luiz Pereira Barreto, "cadeira de operações" do Dr. Desidério Stapler, "massas alimentícias" fabricadas pela Fratelli Secchi ${ }^{13}$ e "mosaicos ferrólitos" patenteados por Amilcari Lusverdi na Argentina e no Brasil. ${ }^{14}$

Lusverdi, sobre quem não localizamos informações, não foi o único expositor dali a utilizar esse recurso de referendamento. Se Calixto não precisava comprovar a autoria da pintura que expunha, precisava legitimá-la: por isso, anexou a ela a "carta parecer do grande pintor brasileiro Victor Meirelles", que cumpria função laudatória convertendo sua apreciação em reputação para o artista $^{15}$.

A Arte e a Técnica, nesse conjunto de objetos, pareciam completar-se na medida em que as invenções podem ser compreendidas sob a óptica metafórica do desejo republicano de progresso e a pintura histórica como celebração das origens. Com isso, estabelecem uma conexão visual e material entre o passado e o presente, tornando tão eloquente o vínculo entre os homens colonial e republicano quanto a superação do primeiro pelo segundo. Era esse o apelo que José Ignácio da Glória fazia no Vicentino de 03 de abril daque- le ano, outorgando a si mesmo, na intenção de ser seguido por seus leitores, a responsabilidade em promover as artes e as indústrias, "principaes mananciaes do bem estar do povo"16.

Na primeira sala da "Exposição Historica e Archeologica", a partir do que se pode inferir pelas descrições dos objetos legadas pelos jornais de época, havia a preocupação de auto-promoção, por parte dos expositores e de suas invenções, produtos, ou obras de arte - e, embora Calixto tivesse planejado toda a decoração para as festividades - e até do monumento público - ele não nos parece ter sido uma exceção. Aos quarenta e seis anos, o pintor já contava com trânsito entre as elites locais e já havia tido uma de suas telas em grande formato adquiridas pelo governo republicano paulista ${ }^{17}$, embora ainda precisasse consolidar sua reputação artística como pintor de História e intelectual - daí, enfim, a estratégica inauguração da "Fundação de São Vicente" durante o $4^{\circ}$ Centenário do Descobrimento, utilizando-se da força centrípeta de sua publicidade pelo Estado de São Paulo.

Essa estratégia, se aparentemente exagerada, é mais bem compreendida se avançarmos ao que estava previsto para o dia seguinte: o dia 22 de abril, por ser a data oficial de celebração do descobrimento cabralino, foi o coração das festividades vicentinas. A seguir, vejamos por que. 
III.

Um mês antes do início das comemorações, o comendador João Manuel Alfaya Rodrigues havia se reunido com o coronel Fernando Prestes de Albuquerque e com D. Antônio Cândido de Alvarenga, presidente do Estado e bispo diocesano, a fim de convidá-los a participarem das programações vicentinas ${ }^{18}$.

Essas duas autoridades (civil e religiosa) estiveram presentes especialmente no dia 22 de abril, cada qual tendo participação notória nas atividades: pela manhã, o bispo D. Antônio Alvarenga celebrou a missa campal e, à tarde, após participarem do banquete oferecido pela Commemoradora aos convidados especiais, seguiriam para o Panthéon, onde ocorreria o préstito histórico.

18. Cidade de Santos, 24 de março de 1900, p. 01.

19. Vicentino, 03 de maio de 1900, p. 07-13.

20. A respeito do debate sobre João Ramalho, cf. NEVES, op. cit. e CAPELATO, Maria Helena Rolim et FERRETTI, Danilo José Zion. João Ramalho e as Origens da Nação: os paulistas na comemoração do IV centenário da descoberta do Brasil. Revista Tempo, Dep. de História da UFF, v. 4, n. 8 , dez/1999.

21. Vicentino, 03 de maio de 1900, p. 11
O préstito era uma das principais programações previstas para o $4^{\circ}$ Centenário: em ordem cronológica, seguiu um cortejo de personagens de todos os períodos da história do Brasil. Seu narrador, Carlos Escobar, era um exímio orador e já havia proferido suas conferências a convite da Commemoradora em 1899. Era também professor do Grupo Escolar Cesário Bastos, em Santos, e já colaborara com colunas em vários jornais nos anos 1890.

Como orador, sua função era altamente honorífica, cabendo-lhe emprestar sua erudição e tom professoral aos presentes com a narrativa que acompanhava a encenação teatral. Carlos Escobar se deteve com maior esmero à expedição martim-afonsina e seu desdobramento mais afamado, a fundação da capitania de São Vicente, em 1532. Mas, diferentemente dos episódios anteriores e posteriores, em que podia se valer somente da encenação para ilustrar seu discurso, Carlos Escobar mobilizou ineditamente a pintura inaugurada na antevéspera por Benedito Calixto ${ }^{19}$.

Reproduzido tanto no Vicentino quanto no Cidade de Santos, Escobar chamou a atenção para a aliança de Martim Afonso de Souza com a tribo liderada por Tibiriçá, por intermédio do náufrago português João Ramalho, instalado há muito naquela região ${ }^{20}$. Opondo-se à concórdia, havia Piquerobi: tudo "divinamente" representado na tela de Calixto, "exposta na Escola do Povo"21. Já nessa solenidade (sublinhe-se, restrita às autoridades e aos convidados da Commemoradora), a pintura histórica foi mobilizada por sua potencialidade em comunicar e homologar uma visão oficial do passado de São Vicente e, por extensão, de São Paulo.

Essa referência à obra, além disso, se alinha à estratégia autopromotora de Calixto em relação à elite paulista. Além de permitir que inaugurasse a pintura, a comemoração do $4^{\circ}$ Centenário também lhe propiciou grande visibilidade, valendo-se da capacidade das elites locais em engajar as principais autoridades regionais a estarem ali presentes. 
Se esse discurso de Escobar exortava os espectadores do préstito a visitarem a pintura na Exposição Historica e Archeologica, foi o Vicentino, em edição especial de maio de 1900, que reproduziu integralmente sua imagem da primeira vez. (Figura 2).

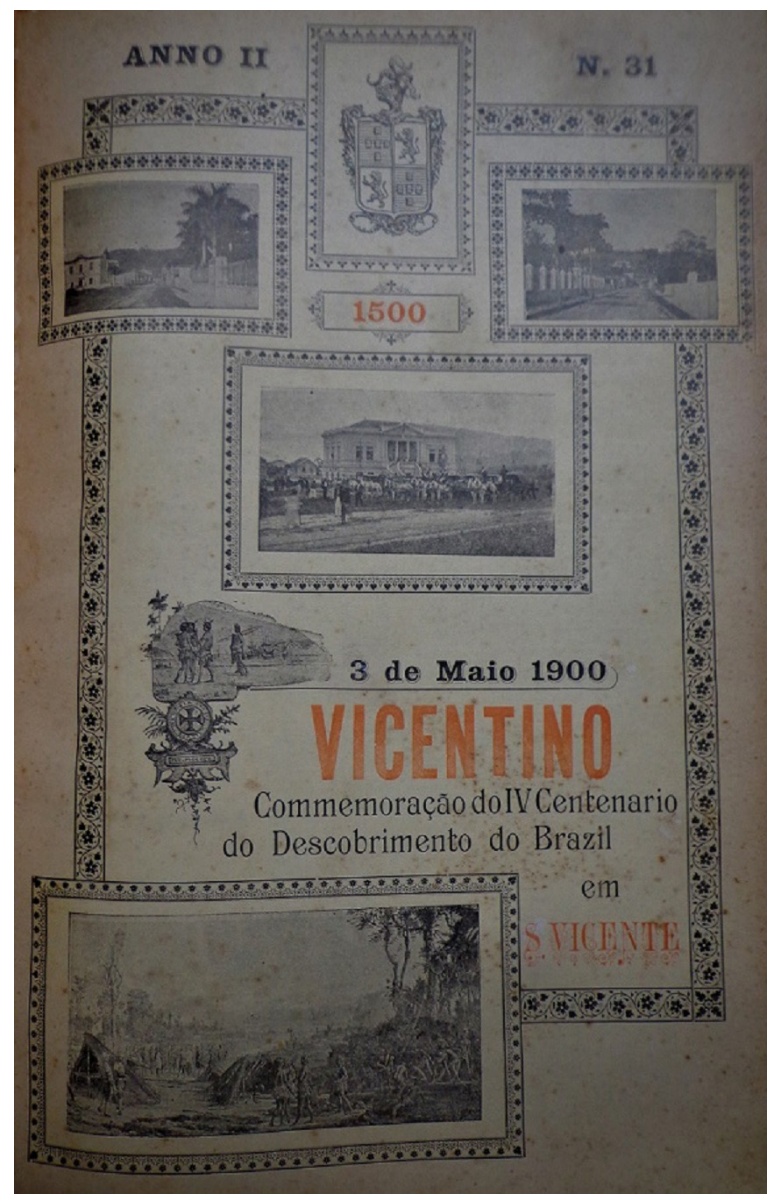

Figura 2. Capa do Vicentino, 03 de maio de 1900. Acervo da Biblioteca da Sociedade Humanitária dos Empregados do Comércio de Santos.
"Integralmente", esclareça-se, porque Calixto utilizou um excerto da pintura como timbre dos papéis de carta utilizados pela Sociedade Commemoradora, tal qual nos permite verificar uma carta assinada por Gregório Inocêncio de Freitas. (Figura 3).

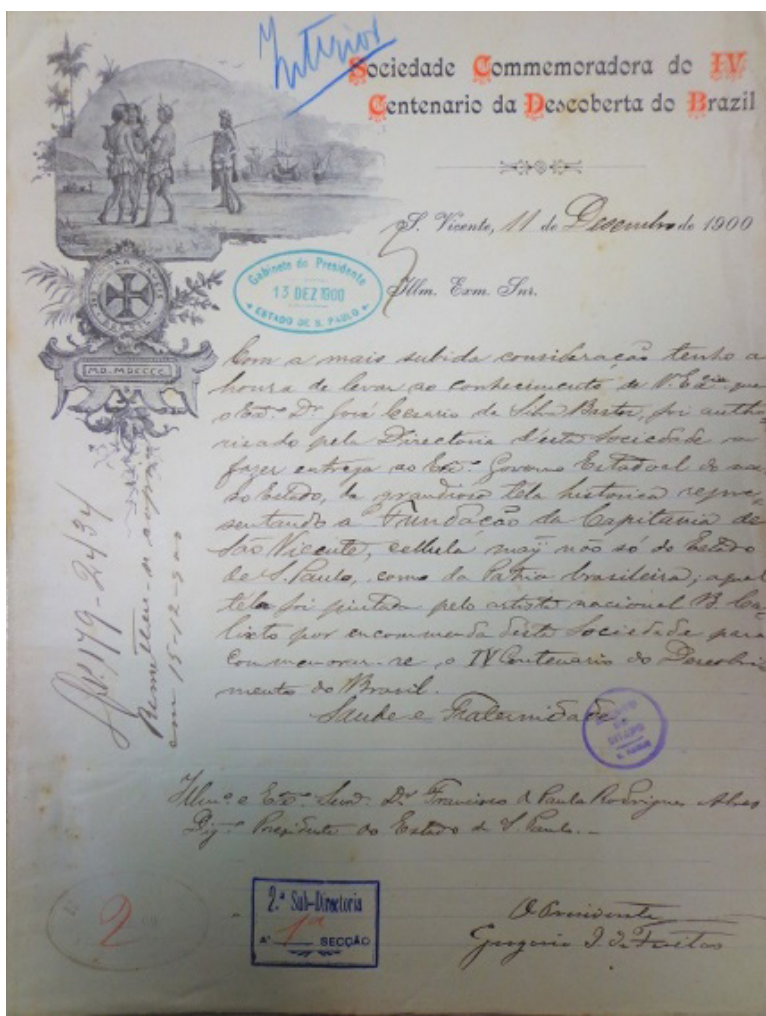

Figura 3. Carta de Gregório Inocêncio de Freitas ao Gabinete da Presidência do Estado de São Paulo, 11 de dezembro de 1900. Arquivo Público do Estado de São Paulo. 
22. O primeiro número do $\mathrm{Vi}-$ centino foi publicado em 29 de agosto de 1899.

23. O Estado de S. Paulo, 15 de agosto de 1899, p. 01: " $A$ Sociedade Commemoradora do IV Centenário do Brasil, fundada em S. Vicente, enviou-nos um desenho do monumento que pretende erigir naquela cidade em 1900. (...) O projeto é executado pelo arquiteto sr. Florimond Colpaert, por indicações e desenhos do sr. Benedicto Calixto. (...) O monumento será colocado na praça Treze de Maio, em frente da barra de S. Vicente e será inaugurado a 22 de abril de 1900."

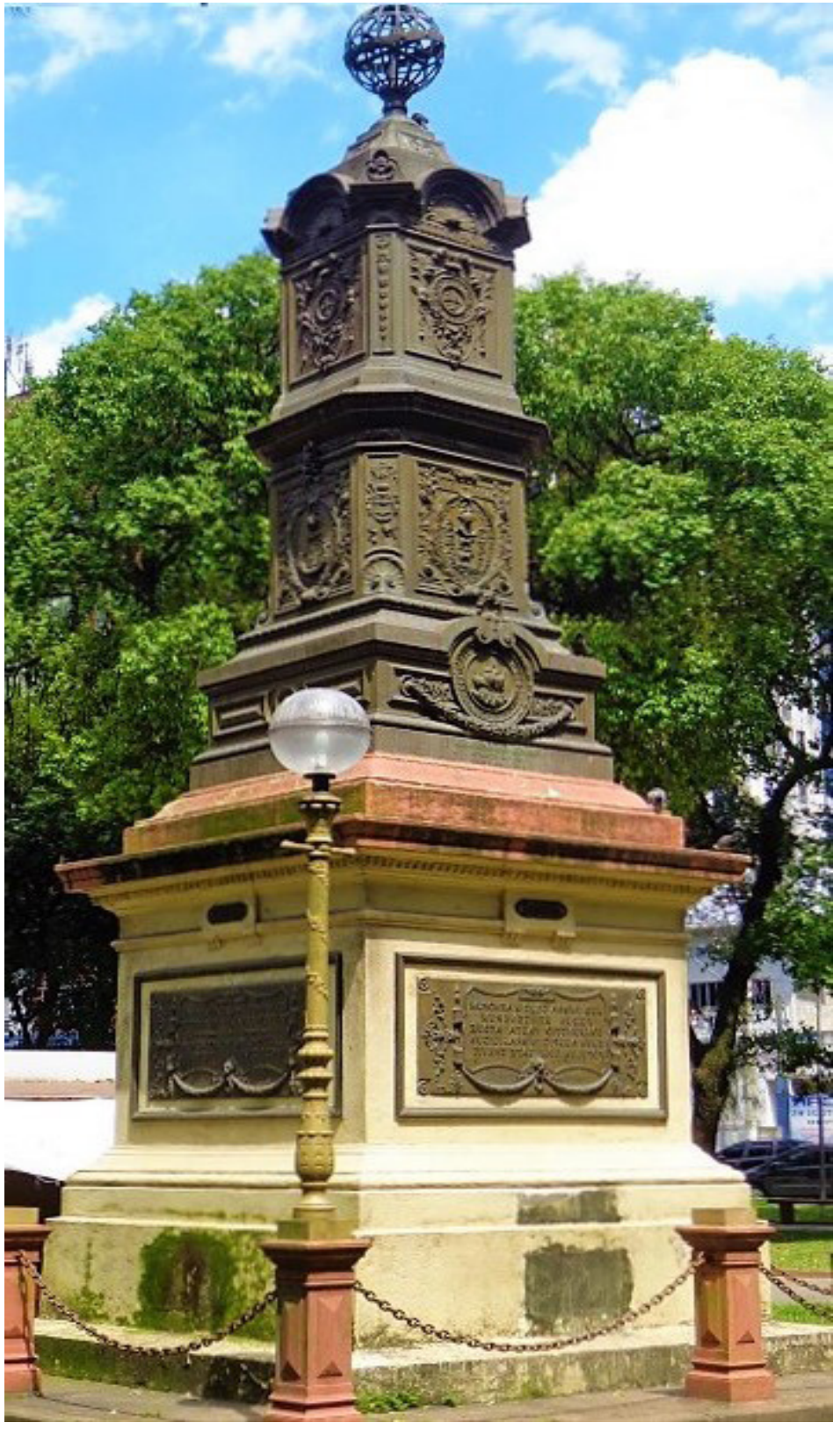

Figura 4. Monumento do $4^{\circ}$ Centenário. Acervo do autor.
É uma prática que se repete também no Vicentino, cuja parte superior foi, desde a primeira edição ${ }^{22}$, ilustrada pelo desenho do monumento (também inaugurado em 22 de abril) do Largo 13 de Maio (Figura 4), com desenho e ornamentação assinados por Calixto. (Figura 5) ${ }^{23}$.

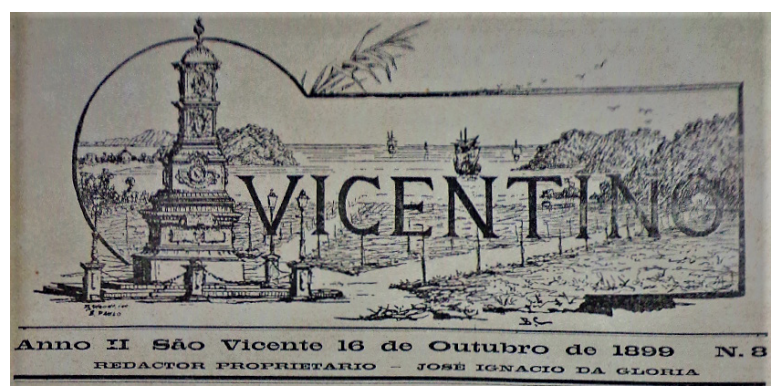

Figura 5. Parte superior do Vicentino. Acervo da Biblioteca da Sociedade Humanitária dos Empregados do Comércio de Santos.

Não seria exagero compreender Benedito Calixto como artífice da configuração simbólica da comemoração vicentina do Descobrimento. Se o evento tinha a intenção de projetar os interesses dos membros da Commemoradora, soube constituir uma estratégia para consolidar sua credibilidade e notoriedade que, embora estivesse centrada na "Fundação de São Vicente", passava transversalmente pela elaboração das artes e do programa decorativo das festividades.

Prova disso é a menção feita ao pintor por Carlos Escobar, consolidando todas as representações teatrais encenadas sequencialmente no préstito histórico pelas ações dos membros da Sociedade Commemoradora. O tom grandiloquente in- 
24. Vicentino, 03 de maio de 1900, p. 06: "Benedicto Calixto foi a cabeça pensante da Commemoradora (...)."

25. Vicentino, 03 de maio de 1900, p. 07.

26. Revista da Semana, edição especial, janeiro de 1902. Acervo da Biblioteca da Sociedade Humanitária dos Empregados do Comércio de Santos. tenciona laurear nominalmente os feitos de seus principais colaboradores. É nesse sentido que Calixto aparece como "cabeça pensante" da associação, tendo seu nome ovacionado ao lado de participantes notórios, como José Ignácio da Glória e Alfaya Rodrigues ${ }^{24}$.

Recorrendo aos exemplos legados pela História desde as pirâmides egípcias, os arcos do triunfo romanos e as colunas parisienses -, Escobar entende que a Sociedade Commemoradora, então "instruída pelos séculos", fora capaz de prover a contribuição desejada às gerações futuras. Loquaz, o parágrafo de encerramento merece reprodução integral, tal qual aparecera aos leitores do Vicentino, em maio de 1900:

A Commemoradora rendeu homenagem aos antepassados, e chamou para a nossa historia a attenção dos contemporaneos. Mas os seus membros passarão como sombras; e daqui a cem annos sò o pincel inspirado de Calixto e o cadinho magico de João Niel contarão aos vindouros as agonias da incommensuravel dedicação dos patriotas. E os vindouros dirão: "Os nossos avòs lembraram-se de seus antepassados; mandemos-lhes tambem nas azas de um beijo uma prece fervorosa."25.

Na perspectiva de Escobar, os esforços da Sociedade Commemoradora apenas não sucumbiriam ao juízo do tempo em função dos protagonismos de Benedito Calixto e de João Niel, artífices de repositórios materiais da memória da associação: representantes das artes e da indústria, o monumento e a pintura histórica seriam os credores do intento de celebrar a participação do Estado de São Paulo na história do Brasil, mas, sobretudo, da participação vicentina na formação histórica do território paulista - e, por extensão, da necessidade simbólica que essa comemoração pública representava para que as elites santista e vicentina pudessem se projetar no regime republicano ainda em vias de consolidação.

Essa propaganda é observável além do contexto estrategicamente mobilizado por Calixto para inaugurar a "Fundação de São Vicente". Conforme demonstramos, a pintura foi prontamente apropriada durante o $4^{\circ}$ Centenário do Descobrimento do Brasil, ilustrando tanto o discurso de Carlos Escobar para as autoridades do Estado de São Paulo quanto a edição comemorativa do Vicentino.

A potência de sua apropriação, no entanto, extravasou sua exibição in loco e esse ambiente inicial. Por isso, é fundamental que nos atenhamos ao processo de reprodução e circulação da imagem da pintura, que ajudam a compreender o intento autocelebrativo em curso nas cidades de São Vicente e de Santos em fins do século XIX. Nesse sentido, o primeiro exemplo mobilizado é a edição especial da Revista da Semana, publicada em janeiro de 1902 e dedicada à cidade de Santos ${ }^{26}$. 
27. Revista da Semana, janeiro de 1902, p. 36: "Reside, actualmente, em S. Vicente, que, com a riqueza de sua historia tem offerecido áquele exímio pintor assumpto para quadros de grande valor artístico. Os diversos trabalhos publicados no presente numero são um attestado brilhante do pujante talento e do incontestável merecimento de Benedicto Calixto."
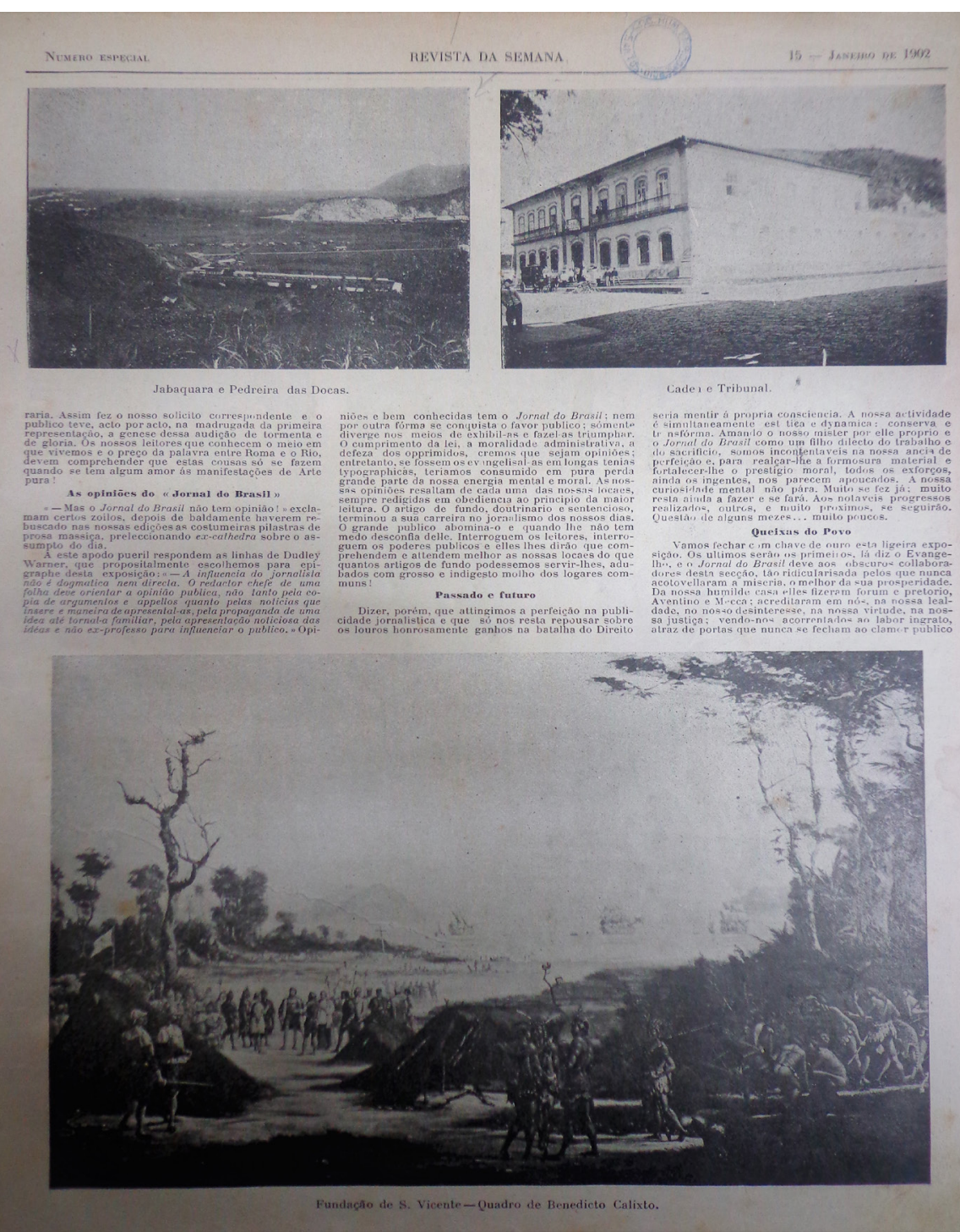

Figura 6. Revista da Semana, edição especial de janeiro de 1902, p. 15. Acervo da Biblioteca da Sociedade Humanitária dos Empregados do Comércio de Santos.
IV.

Em fins do século $X I X$, o progresso urbanístico foi ponta de lança da propaganda das cidades sul-litorâneas paulistas. Foi isso que Anatólio Valladares, então jornalista da Revista da Semana responsável pela matéria, registrou durante sua estadia de um mês, parecendo impressionado pelas reformas urbanas e portuárias que os santistas vinham empreendendo, simbolizadas pelo saneamento, iluminação, transporte, pelos "monumentos seculares" e pelos "edifícios de construcção moderna".

Em quarenta e uma páginas, cabe mencionar, a Revista da Semana reproduziu a soma de duzentas e doze imagens, número que, por si só, advoga uma intenção deliberada por impressionar visualmente o leitor: elas registravam os logradouros, edifícios (fachadas e interiores), monumentos (incluindo o do Descobrimento, em São Vicente) e retratos diversos de personalidades dentre eles, o de Benedito Calixto ${ }^{27}$.

Contrastando com as fotografias elogiosas da modernidade e do progresso santista havia a imagem da pintura "Fundação de São Vicente". A correlação entre a tela e as demais imagens presentes na Revista da Semana é homóloga à construída pela exibição na "Exposição Historica e Archeologica". (Figura 6). 
Se as invenções mecânicas dos expositores que dividiram a primeira sala com Benedito $\mathrm{Ca}$ lixto eram representantes da indústria paulista, a "construcção moderna", tal qual descrita por Anatólio Valladares, representavam o progresso da vida urbana santista no alvorecer do século XX: nesse sentido, à pintura de Calixto é atribuída uma nova camada semântica, não mais restrita à intenção de promover o artista como legítimo representante local das artes, tampouco pelo ensejo celebrativo da expedição martim-afonsina, mas, isso sim, à representação da cidade per se, no momento de sua fundação.

Essa dissintonia (ou seja, apropriar-se de uma representação artística da fundação de São Vicente como anteparo ao elogio do progresso material de Santos republicana) é mais bem compreendida se levarmos em conta o alinhamento das elites locais em torno de Cesário Bastos - orador da Sociedade Commemoradora, além dos cargos já mencionados - e de que, àquele momento, o grupo de interesses do qual Calixto fazia parte intencionava celebrar o início da colonização do território a partir do litoral sul de São Paulo.

"Refundadas" pela República no opúsculo do século XIX, Santos e São Vicente procuravam afirmar, instrumentalizando a história como recurso simbólico, "(...) todo o seu progresso material e toda a superioridade de seu espirito nos tríplices domínios das artes, das sciencias e das letras (...).", angariando visibilidade junto à presidência do Estado de São Paulo e, por extensão, da República - então dirigida pelo cafeicultor e político perrepista Manuel Ferraz de Campos Salles $(1841-1913)^{28}$.

A modernização representada pelas obras públicas urbanas, pelo mobiliário monumental, pela arquitetura e pelo replanejamento urbano, assim, ancorava-se na representação de uma fundação colonial marcada pela pacificidade entre as partes e pela paisagem natural acolhedora, inofensiva e irresistente à ação iminentemente política.

No segundo plano da composição, o núcleo principal de personagens biográficos é circundado, nos demais planos, tal qual notou Ulpiano Toledo Bezerra de Meneses, por suportes simbólicos que, embora antevissem a ocupação humana, não atestavam fixidez, testemunhando seu caráter semipermanente. (MENESES, 1990, p. 42-43).

Restrito a um acordo político, o ato fundacional atenta para a imaterialidade da cidade colonial e, ao mesmo tempo, informa o patamar projetual onde está inserida a cidade republicana nascente, muito menos como continuidade desse passado colonial do que compreensão desse contexto como uma oportunidade de recomeço a partir da comunhão entre o homem e o território que habita.

Outro exemplo desse processo são os cartões postais em circulação no início do século XX. 
29. Alinhando-se a proposta metodológica de U. T. B. de Meneses, que entende "iconosfera" como uma das dimensões integrantes do "visual" e que, conjuntamente ao "visível" e a "visão", ajudam a mapear e observar o regime escópico, definido por Christian Metz como discursos e práticas que condicionam, de maneira autocomplementar, a experiência visual em circunstâncias historicamente situadas. MENESES, Ulpiano Toledo Bezerra. Fontes visuais, cultura visual, história visual. Balanço provisório, propostas cautelares. IN: Revista Brasileira de História. São Paulo, v. 23, $n^{\circ} 45,2003$, p. 30-31.
O estudo de Fraya Frehse sobre as fotografias reproduzidas nos postais da época, que tinham a cidade de São Paulo como objeto de registro, aponta o contraste evidente entre uma paisagem urbana marcada tanto pelos edifícios coloniais quanto por edifícios modernos. Se eles advogaram um anseio pelo progresso, também testemunhavam a coexistência das diferenças sociais, para além do "desencontro de tempos históricos". (FREHSE, 2000)

É para esse mesmo sentido que aponta um mapeamento de cartões postais ilustrados por temas relativos ao progresso das cidades sul-litorâneas de São Paulo. Por exemplo, um cartão de 1897 foi ilustrado com a imagem da estrada de ferro que ligava Santos à capital; outro, datado de 1902, traz um panorama da paisagem urbana de Santos e, cinco anos depois, um terceiro e último exemplo promovia as obras de saneamento em curso nessa cidade (GERODETTI e CORNEJO, 2001, p. 11; 14; 184).

Calixto observava com grande atenção as mudanças pelas quais passavam as cidades do litoral sul. Com acurácia, suas pinturas documentaram as transformações da paisagem portuária e urbanística entre as décadas de 1870 e 1890 e, tal qual Caleb Faria Alves observou, é sob esse ângulo que podemos compreender como o pintor equacionava suas preocupações artisticamente.
Em suas representações do porto de Santos feitas entre 1875 e 1898, Calixto se atentou em demarcar o curso do processo de modernização. Em "Porto de Santos" (óleo sobre tela, 32 x 56 $\mathrm{cm}, 1875)$ as atividades no cais são cotidianas e apontam a comunhão entre o tempo do homem e da natureza, enquanto na "Vista da Cidade de Santos" (óleo sobre tela, 146 × 290 cm, 1898), já estão conjugadas às modernizações em curso, já tendo os trapiches desaparecido e os armazéns, outrora dominantes, incorporados a imagem de uma cidade em franco desenvolvimento. (ALVES, 2003, p. 208-211)

Sendo um dos artífices das imagens da cidade de Santos, articuladas aos interesses das elites comerciais, não é surpreendente que a obra de Calixto tenha sido utilizada nas ilustrações de postais, segundo notaram C. F. Alves (2003) e Gerodetti e Cornejo (2001). A projeção da ideia de progresso harmonioso e cordato foi transferida para a tela "Fundação de São Vicente", reputando responsabilidade à representação artística da cena histórica em alimentar o ambiente iconosférico em formação ${ }^{29}$.

A impressão da imagem da pintura nos cartões postais tinha, por certo, o objetivo de exaltar e divulgar o trabalho artístico de Calixto. No entanto, devem-se considerar as potencialidades em fazer circular uma imagem que se desejava visível e 


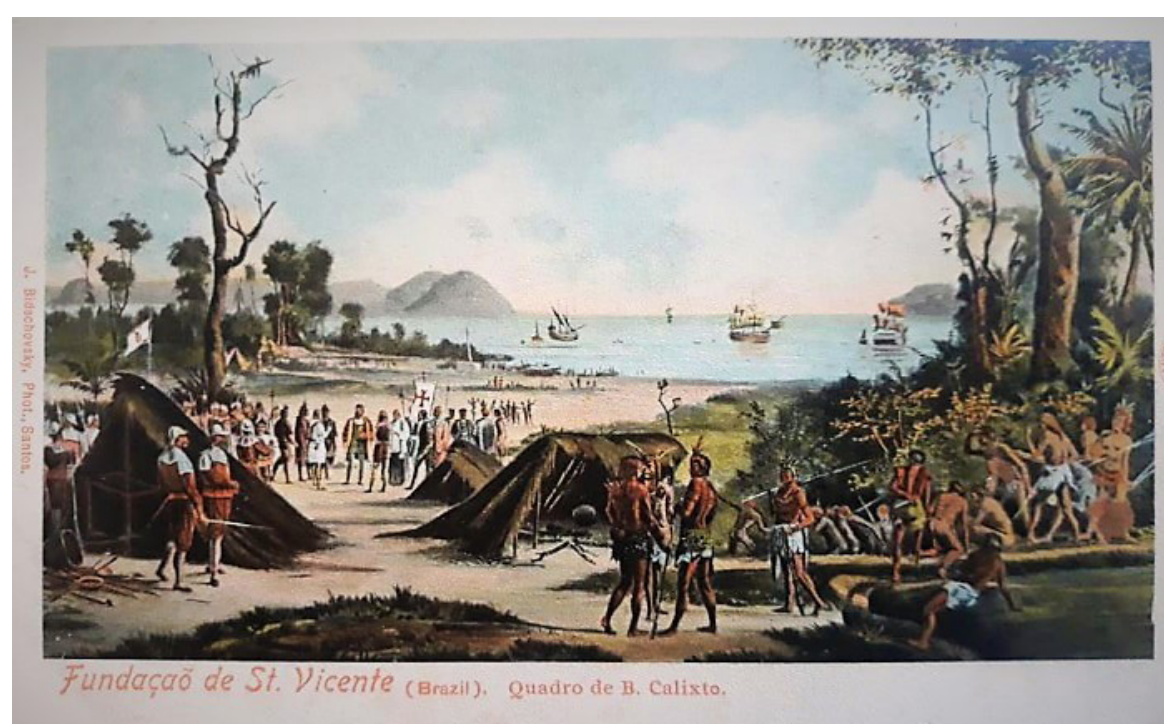

Figura 7. Cartão postal, 1902. Coleção do autor.

30. Embora tenha sido o autor de inúmeras imagens para cartões postais paulistas durante a década de 1900, a biografia de José Bidschovsky ainda é pouco conhecida. Segundo Boris Kossoy, atuava em Santos e em Piracicaba. Cf. KOSSOY, Boris. (ed.) Dicionário Histórico-Fotográfico Brasileiro. Fotógrafos e ofício da fotografia no Brasil (1833-1910). São Paulo: Instituto Moreira Salles, 2002, p. 83. Para as informações adicionadas, cf. <www.coisasantigas.wordpress.com/tag/fotografos-piracicabanos $>$, consultado em 11 ago. 2019.

31. Cf. supra.
Figura 8. Cartão postal, 1902. Coleção do autor.

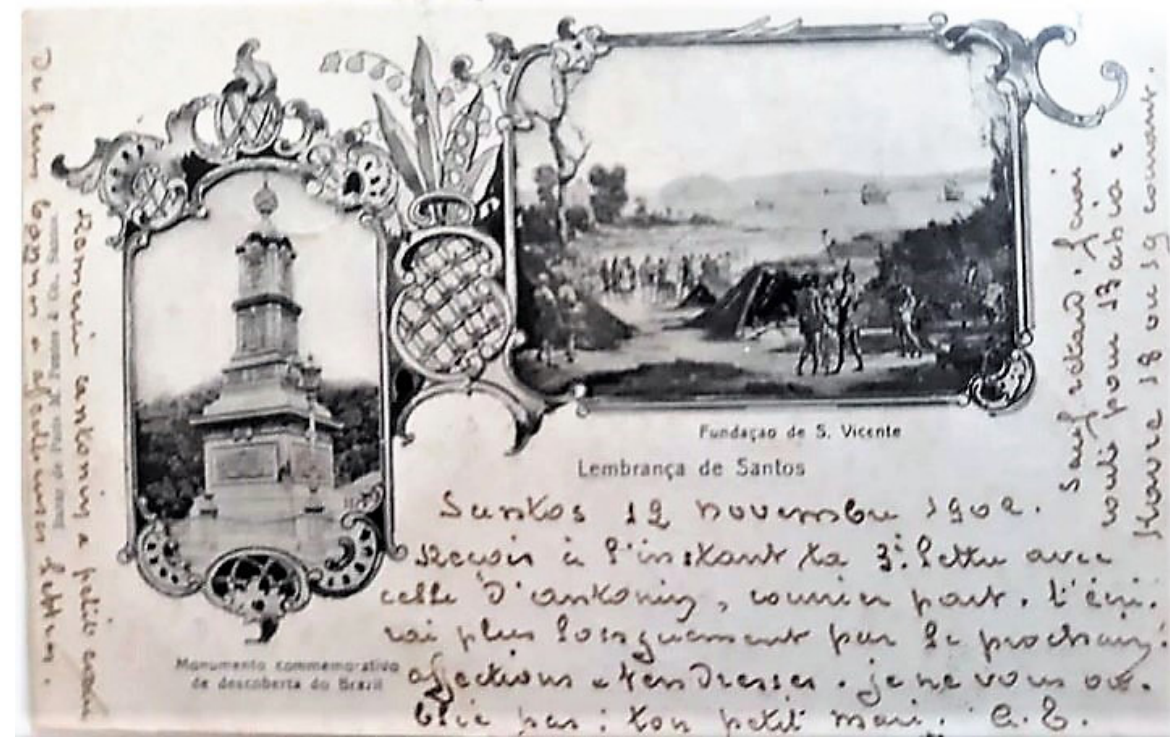

apreensível, convergindo-a aos demais suportes que alicerçavam a demonstração do progresso e da modernidade na projeção de uma história local solene e, por isso mesmo, a ser vista e celebrada.

O primeiro postal localizado traz uma reprodução fotomecânica colorizada, com autoria de José Bidschovsky, do estúdio piracicabano "Vienna Photographia"30. (Figura 7). O segundo, também de 1902, reproduz as fotografias dos principais símbolos da comemoração do $4^{\circ}$ Centenário: o monumento público e a pintura. (Figura 8) .

Intitulado "Lembrança de Santos", o postal ajuda a observar como o discurso simbólico-visual da Sociedade Commemoradora extravasou as festividades vicentinas, impulsionando-o como lugar de memória de alcance supralocal. As imagens desse cartão retomam aquilo que Carlos Escobar mencionava ter poder para transcender o tempo e o que fizeram os membros da Commemoradora: a pintura "Fundação de São Vicente", pelo pincel de Calixto, e o monumento surgido pelo "cadinho mágico de João Niel"31.

Enfim, ainda caberia um exemplo derradeiro: o encarte "São Paulo Antigo e São Paulo Moderno", lançado em virtude da comemoração do $350^{\circ}$ aniversário da fundação de São Paulo, “(...) com muitas gravuras e um curto resumo histórico dos 
principaes edifícios ou dados biográficos dos vultos notaveis cujos retratos forem publicados"32. (Figura 9).

Ao longo de dezesseis páginas, esse volume inaugural reproduzia, ao sabor do que fizera dois anos antes a Revista da Semana, uma série fotográfica dos edifícios públicos arquitetonicamente monumentais, como o do Palácio do Governo ${ }^{33}$, erguido em 1898, e coloniais, como a Igreja do Carmo e da Venerável Ordem Terceira ${ }^{34}$.

A narrativa sobre a história da fundação de São Paulo, não bastassem as mudanças observáveis na cidade em vias de modernização, se iniciava precisamente na fundação da capitania de São
32. São Paulo Antigo e São Paulo Moderno 1554-1904. São Paulo: Vanorden \& Cia, vol. 01, 1905, capa.

33. Idem, p. 11.

34. Idem, p. 13

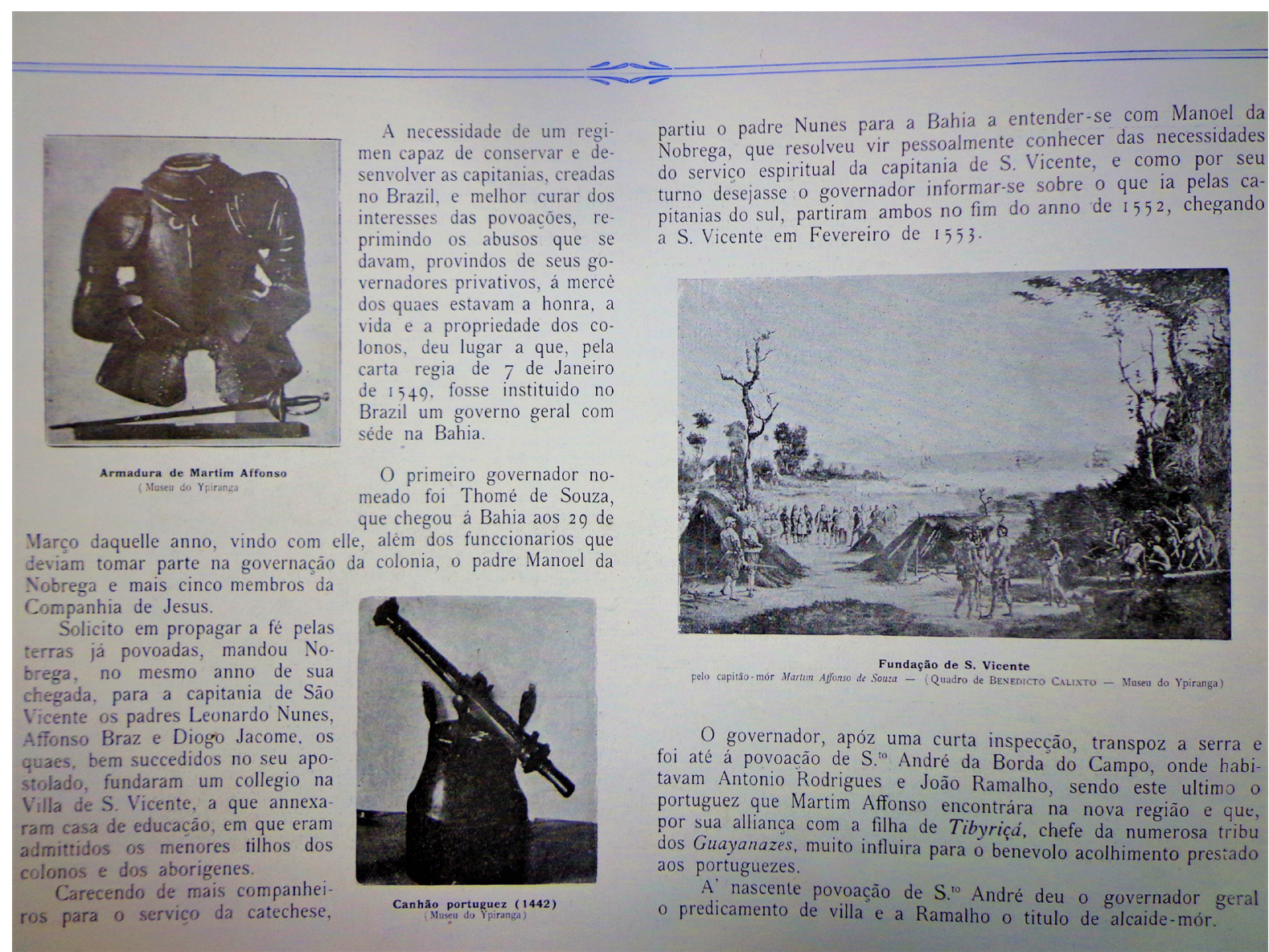

Figura 9. São Paulo Antigo e São Paulo Moderno, 1905. Acervo do Arquivo Público do Estado de São Paulo. 
35. Correspondência de Hermann von Ihering ao Secretário do Interior, 12 de novembro de 1900, Acervo do Arquivo Público do Museu Paulista da USP.

36. A "querela do pagamento" é bem compreendida a partir da correspondência trocada entre Calixto, o primeiro secretário e o tesoureiro da Sociedade Commemoradora, onde o pintor reivindica pagamento pela pintura e atesta ter cumprido as funções que lhe fo-
Vicente, em 1532 - dentre outras, uma prova disso é a pintura "O Primeiro Desembarque de Pedro Álvares Cabral" (óleo sobre tela, 330 x 190 cm, 1900), de Oscar Pereira da Silva, ter sido nomeada como o "Desembarque de Martim Affonso de Souza".

A Editora Vanorden, já nas primeiras páginas do encarte, escolheu reproduzir a gravura de Martim Afonso de Souza e o brasão de sua família. A seguir, imagens de três objetos: uma armadura que se dizia ter pertencido ao navegador, uma canhoneira utilizada durante a expedição por ele comandada e, por fim, a imagem da "Fundação de São Vicente". A conjugação semântica entre elas, além de ambientar visualmente o leitor sobre a expedição martim-afonsina, guardava um aspecto até então inédito.

atribuídas, listando-as detalhadamente. Cf. Carta de José Leite da Costa Sobrinho a Benedito Calixto, 25 de julho de 1903; Carta de Antônio Militão de Azevedo a Benedito Calixto, 25 de julho de 1903. Cf. Dossiê Benedito Calixto - Fundo IHGSP/ APESP.

37. Cf. Annaes da Câmara dos Deputados de São Paulo, 1905, p. 621; Annaes do Senado do Estado de São Paulo, 1905, p. 571

Se no Vicentino de maio de 1900, nos cartões postais e na Revista da Semana de 1902, a "Fundação de São Vicente" havia sido mobilizada como o anteparo às imagens que propagandeavam o ímpeto da modernização sul-litorânea e de Benedito Calixto em galgar maior projeção artística, no São Paulo Antigo e São Paulo Moderno houve uma inflexão importante na história da pintura: ali, não era referenciada apenas como obra de Benedito Calixto, mas como uma pintura do
A incorporação da "Fundação de São Vicente" ao acervo do Museu Paulista foi, a priori, fruto de doação à presidência do Estado de São Paulo feita pela Sociedade Commemoradora. A tela chegou ao Museu, acompanhada por Benedito Calixto, em 10 de novembro de 1900 e, por vontade do pintor, foi colocada na sala B-11, passando a ser exibida junto às coleções de paleontologia e mineralogia ${ }^{35}$.

Pelo acordo estabelecido com Calixto, a associação devia lhe pagar dez contos de réis pela pintura e contrapartida aos serviços decorativos prestados. Mas, não foi isso que aconteceu e, cinco anos após o fim das comemorações, ainda não havia sido remunerado ${ }^{36}$. Museu Paulista.
Isso fez com que o pintor remetesse uma petição à Câmara dos Deputados, onde alegava que continuava sendo proprietário da pintura, tendo o direito de reavê-la. A querela foi efetivamente resolvida em dezembro de 1905, com a discussão da Lei Orçamentária para o ano seguinte, tendo sido previsto o pagamento de cinco contos de réis para o pintor, incorporando a tela "Fundação de São Vicente" ao patrimônio público do Estado de São Paulo em definitivo ${ }^{37}$. 
38. Sobre essa transferência e a consequente formação do núcleo inicial da Pinacoteca do Estado de São Paulo, cf. NERY, Pedro. Arte, pátria e civilização. A formação dos acervos artísticos do Museu Paulista e da Pinacoteca do Estado de São Paulo. (1893-1912). Dissertação de Mestrado, Programa de Pós-Graduação Interunidades em Museologia da Universidade de São Paulo, 2015.

39. Dentre os retratos históricos, seis foram encomendados a Benedito Calixto menos de um ano após a entrada da "Fundação de São Vicente" no Museu: D. Pedro I, Padre José de Anchieta, José Bonifácio de Andrada e Silva, entregues em 1902, e
Padre Bartholomeu de Gusmão, Domingos Jorge Velho e Vicente Taques Góes Aranha, Sargento-Mor de Itu, entregues no ano seguinte. Sobre o retrato de Domingos Jorge Velho, cf. MARINS, Paulo César Garcez. Nas matas com poses de reis: a representação de bandeirantes e a tradição da retratística monárquica europeia. IN: Revista do IEB, n. 44, fev. 2007; PITTA, Fernanda Mendonça. Os pincéis escrevem a história no "Teatro da Memória" - O trabalho artístico, intelectual e político de Benedito Calixto nas encomendas de retratos históricos do Museu Paulista (1900-1906) Relatório não publicado pela autora, a quem agradeço por disponibilizá-lo.
Assinale-se que, concomitantemente a aquisição, José Cardoso de Almeida, o Secretário de Estado dos Negócios do Interior e da Justiça, enviava a Hermann von Ihering uma lista com quatorze pinturas que deveriam ser transferidas de imediato do Museu Paulista para a Galeria de Pinturas do Liceu de Artes e Ofícios ${ }^{38}$.

Disso, chama a atenção que "Partida da Monção" (óleo sobre tela, 640 x 390 cm, 1897), de José Ferraz de Almeida Júnior (1850-1899), e "Primeiro Desembarque de Pedro Álvares Cabral" foram transferidas, permanecendo ali apenas a "Fundação de São Vicente", o que nos permite concluir que essa pintura tenha sido adquirida pelo governo paulista especificamente para a coleção do Museu Paulista, conjugando-se aos retratos históricos ${ }^{39}$ e à "Independência ou Morte" (óleo sobre tela, $760 \times 415 \mathrm{~cm}, 1888)$.

O imediatismo da reprodução da imagem da "Fundação de São Vicente" no Vicentino, na Revista da Semana e nos cartões postais pode ser observada sob a luz da necessidade simbólica que a pintura representava para o intento autocelebrativo da elite sul-litorânea paulista. Em nossa interpretação, o envio da tela como doação ao governo do Estado e, em sequência, sua exibição no Museu Paulista (que, esclareça-se, interessava também a Calixto por se tratar da oportunidade de ter sua primeira pintura histórica em exposição no único museu do Estado de São Paulo à época), homologa assertivamente a in- tenção dos membros da associação comemorativa em consolidar seu lugar simbólico no Estado de São Paulo a partir da projeção da visibilidade do passado colonial vicentino.

No limite, o Museu Paulista fora compreendido como o legítimo receptor-difusor do visível desejado pela Sociedade Commemoradora, retomando Meneses (2003, p. 30), mas que a pintura, além de "dar a ver" o passado colonial vicentino, era também ponte entre os membros da Sociedade Commemoradora e o governo estadual, tendo Calixto sido o artífice dessa conexão: cabia aos paulistas que se lembrassem de suas origens: a capitania de São Vicente, fundada por Martim Afonso de Souza em 22 de janeiro de 1532.

Empenhamo-nos, até então, em demonstrar que o processo de remodelamento das cidades do litoral sul paulista e a comemoração vicentina do $4^{\circ}$ Centenário foram o epicentro dessa necessidade simbólica, tendo sido a imagem da "Fundação de São Vicente" mobilizada como resposta a esse processo, em que, embora atrelada ao Museu Paulista, é observada também a partir de seu contexto de produção e exibição inaugural.

Essa curta bifurcação se encerra no encarte pedagógico São Paulo Antigo e São Paulo Moderno. Observa-se, nessa ocasião, uma ressemantização que, no limite, parece recobrar a acepção inicialmente veiculada pela Sociedade Commemoradora durante o $4^{\circ}$ Centenário do Descobrimento. 
40. Segundo Meneses (2003, p. 15), a "iconosfera" é um "conjunto de imagens que é ou está socialmente acessível", e que tomamos aqui como direcionamento da análise pretendida. Em tempo, nota-se o agenciamento da tela "Fundação de São Vicente" em dois ambientes iconosféricos distintos, não necessariamente excludentes entre si, mas tampouco complementares, sendo o primeiro oriundo das comemorações vicentinas e o segundo ao pertencimento à coleção do Museu Paulista.

41. Vicentino, 03 de maio de 1900, p. 11: "Museu Paulista - Armadura de Martim Affonso de Souza - Peça de artilheria do século 16 (colubrina) (...)."

42. Segundo o Guia pelas collecções do Museu Paulista, a coleção mineralógica estava em exposição nos armários 49 e 50 e continha “(...) amostras dos mineraes mais interessantes do Brazil e tambem de varios outros paizes.": meteoritos, xistos betuminosos, os mármores sorocabanos e a "(...) collecção de minerios e productos da fabrica de ferro de Ipanema, Est de S. Paulo.". coleção paleontológica, por fim, fora organizada nos armários 48 e 51: no primeiro, havia o fóssil do Mesosaurus Tumidus, peixes do período mesozoico, dendrites e troncos de árvore petrificados, enquanto no outro figuravam “(...) numerosos fosseis das diversas partes do mundo e são especialmente interessantes as copias dos famosos reptis Plesiosaurus, Mystriosauus e Ichthyosaurus." Cf. IHERING, Rodolpho von. (ed) Guia pelas ções do Museu Paulista. São Paulo: Typographia Cardozo Filho, 1907, p. 102-104.

43. E. g. Ana Cláudia Fonseca Brefe: "É o caso, por exemplo, da tela Fundação de São Vicente, de Benedi-
Ao ser associada às imagens de outros objetos da coleção histórica, como a armadura de Martim Afonso e a colubrina (e até mesmo à pintura de Oscar Pereira da Silva - erroneamente intitulada, recobre-se, como Desembarque de Martim Affonso), a "Fundação de São Vicente" é incorporada à iconosfera ${ }^{40}$ da representação histórica e atrelada à vida institucional. Em tempo, essa armadura e a colubrina foram enviadas pelo Museu Paulista para a Exposição Historica e Archeologica. Quase um “destino manifesto”, a pintura fora inaugurada ao redor dos objetos pertencentes a uma coleção à qual seria incorporada alguns meses depois ${ }^{41}$.

Em 1905, cinco anos após a inauguração da tela durante a comemoração do Descobrimento, Calixto havia composto a representação da fundação vicentina, cuja força representacional foi prontamente testemunhada pela reprodução já durante esse primeiro quinquênio. Não é surpreendente que a Câmara dos Deputados tenha optado por incorporá-la definitivamente à coleção histórica do Museu Paulista, mantendo-a ali em exibição. É isso que veremos a seguir.

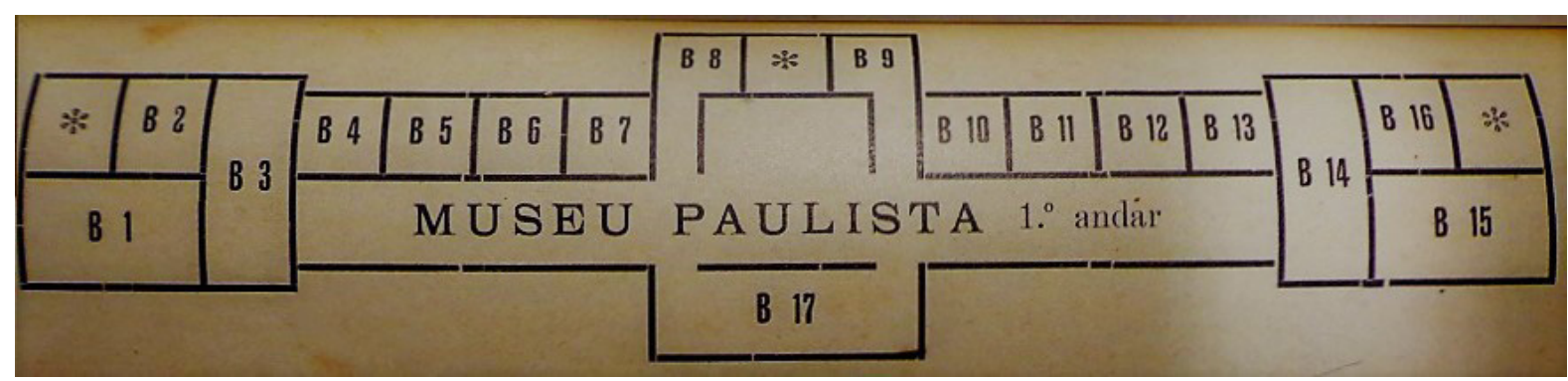

Figura 10. Salas de exposição do Museu Paulista, segundo o Guia de 1907. Acervo da Biblioteca do Museu Paulista da USP. 
to Calixto, disposta na sala B11, dedicada à mineralogia e à paleontologia. Além de pedras e fósseis, a tela ainda divide espaço com pequenos quadros representando gêiseres e paisagens de antigas épocas geológicas (!) como pode ser constatado pela descrição da sala presente no Guia pelas Collecções". Cf. O Museu Paulista: Afonso Taunay e a Memória Nacional (1917-1945). Editora da UNESP, Museu Paulista da USP, 2003, p. 90, n. 04. A autora parece alinhada às impressões legadas por Taunay: (...) Outro facto demonstra o abandono em que a chamada "collecção histórica" se achava. É diffícil explicar, por exemplo, porque fora uma tela representando a Fundação de São Vicente alcandorar-se por cima de um armário de mineraes, na sala de mineralogia e geologia, a quase 4 metros acima do soalho. Nada ou quasi nada no Museu Paulista lembrava o passado de São Paulo.". Cf. TAUNAY, Afonso Teixeira d'Escragnolle. Relatório de Atividades referente ao ano de 1917, p. 15-16. IN: Arquivo Público do Museu Paulista, P5, D33.16 e D.33.17.

44. Decreto $n^{\circ} 249$ de 26 de julho de 1894, Capítulo 01, Artigo $2^{\circ}$. Acervo Histórico ALESP.

45. Sobre a gestão de Afonso Taunay (1917-1946), cf. [cont.] BREFE, op. cit. e OLIVEIRA, Cecília Helena de Salles (org.). O Museu Paulista e a gestão de Afonso

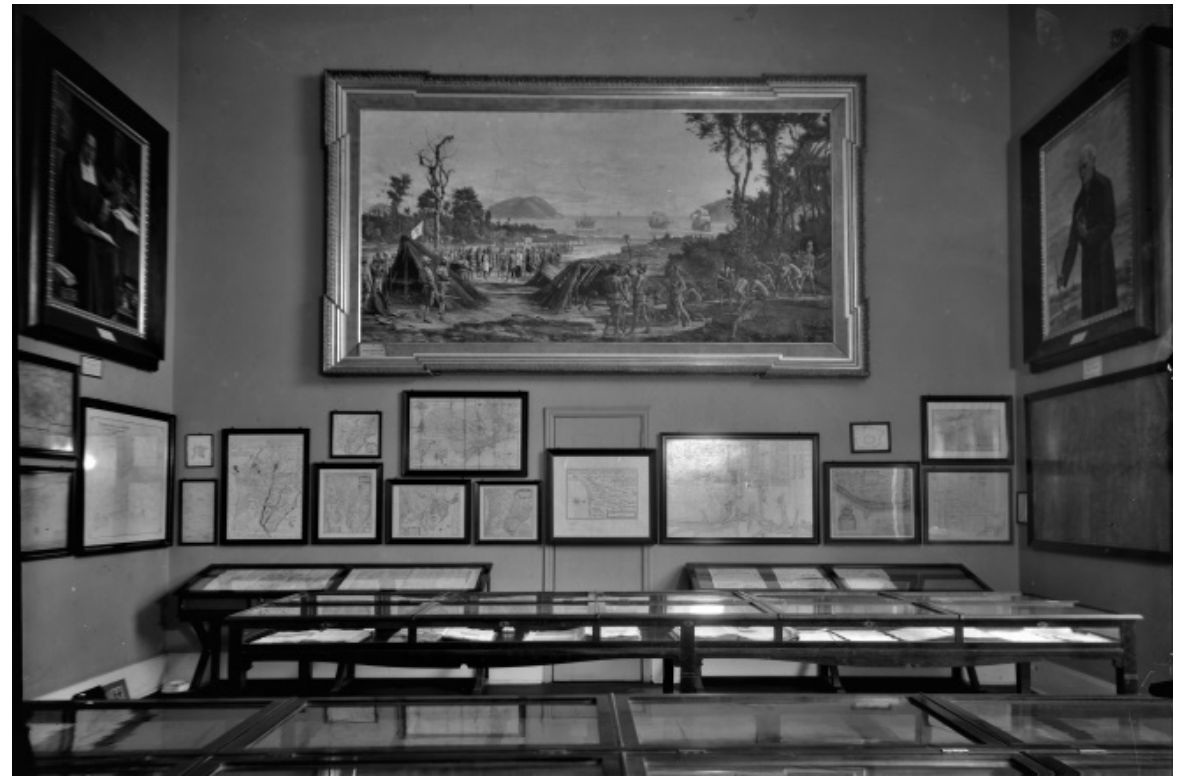

Figura 11. "Fundação de São Vicente" na sala A-10, 1937. Acervo do Museu Paulista da USP.

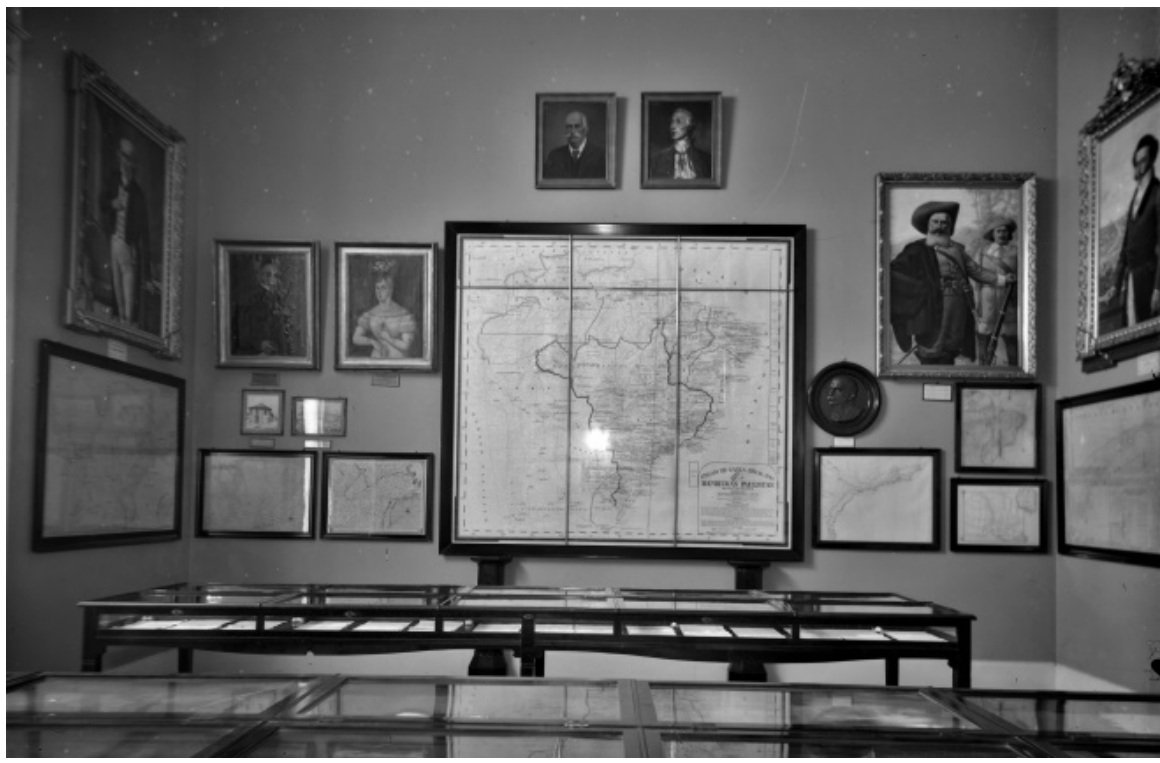

Figura 12. "Ensaio Geral das Bandeiras Paulistas" na sala A-10, 1937. Acervo do Museu Paulista da USP.
Compreender a relação entre essa pintura de $\mathrm{Ca}$ lixto e os demais objetos da sala B-11 representou um desafio incômodo para a historiografia recente, que tomou a perspectiva de Afonso Taunay - substituto de Hermann von lhering e crítico de sua gestão - como argumento para constatar que a alocação da tela era ocasional e que atestava certo desprezo do antigo diretor pela coleção histórica do Museu ${ }^{43}$

Segundo o que pudemos apreender pela descrição do arranjo expositivo, a sala B-11 representava os processos de formação e ocupação do território paulista a partir da história natural e do homem, em que rochas, fósseis e a pintura histórica produziam sentidos relacionais e mutuamente complementares, alinhando-se ao que havia sido previsto no Artigo $2^{\circ}$ do Decreto $n^{\circ} 249$, que caracterizava essa instituição como "(...) museo Sul-Americano, destinado ao estudo do reino animal, de sua historia zoologica e da historia natural e cultural do homem." ${ }^{44}$ e museus do século XIX, que buscavam consolidar uma "história natural do homem". (ALENCAR ALVES, 2001, p. 139).

A "Fundação de São Vicente" permaneceu exposta na sala B-11 até 1917, quando Afonso Taunay, então o diretor interino do Museu, reelaborou a exposição e the atribuiu novos sentidos ${ }^{45}$. Após inaugurar a sala A-07, onde exibiu as coleções de botânica, em setembro de 1917, Taunay passou a organizar a primeira sala de exposição das coleções históricas de sua gestão: a sala $\mathrm{A}-10$, de "cartografia colonial", inaugurada em 24 de dezembro daquele mesmo ano. (Figura 11 e Figura 12) 
Taunay: Escrita da História e Historiografia, séculos XIX e $X X$. São Paulo: Museu Paulista da USP, 2017.

46. Luigi Brizzolara, Adrien van Emelen, os irmãos Henrique e Rodolfo Bernardelli, José Wasth Rodrigues, Domenico Failutti, Alfredo Norfini, Oscar Pereira da Silva e o próprio Benedito Calixto são exemplos de artistas mobilizados por Taunay.

47. Taunay solicitou, em 1929, que a "Partida da Monção" retornasse da Pinacoteca. Junto a ela, recebeu também outras duas: "O Primeiro Desembarque de $\mathrm{Pe}$ dro Álvares Cabral" e a "Fundação de São Paulo" (óleo sobre tela, $340 \times 185 \mathrm{~cm}$, 1907), ambas de Oscar Pereira da Silva, alocando-as, respectivamente, nas salas $\mathrm{A}-09$, dedicada às monções, A-12, de antigas iconografias paulistas e A-15, ao passado de São Paulo. A respeito do retorno destas obras ao $\mathrm{Mu}$ seu Paulista, cf. MONTEIRO, Michelli Cristine Scapol.
Fundação de São Paulo, de Oscar Pereira da Silva. Trajetórias de uma imagem urbana. Dissertação de Mestrado - FAUUSP, 2012, p. 104-105.

48. TAUNAY, A. T. d'E. Guia da Seção de História do Museu Paulista. Imprensa Oficial do Estado de São Paulo: São Paulo, 1937. p. 73.

49. TAUNAY, op. cit., p. 63 "Ennobrece-Ihe a soberba architectura, tão caracteristicamente palacial e dynastica, a presença da grande tela de Pedro Americo: Independencia ou Morte!, quadro famoso, certamente um dos mais populares do nosso paiz, e alvo de innumeras reproduções pictoreas e esculptoreas."

50. Idem, p. 80

51. Idem, p. 88

52. PINTO E SILVA, João. Minha Pátria: Ensino da História do Brazil no segundo anno do curso preliminar. São Paulo: Augusto Siqueira \& C., 1916, p. 20. Acervo LEMAD-DH/USP.
Taunay alocou a "Fundação de São Vicente" ao lado dos retratos de José de Anchieta e Bartolomeu de Gusmão, ambos também da autoria de Calixto, e conferiu centralidade à pintura em grande formato. Não seria exagerado inferir, inclusive, que a pintura detinha certa maestria sobre o arranjo expositivo da sala A-10. Isso ficaria mais evidente quando a "Carta Geral das Bandeiras Paulistas" foi posicionada em frente a ela, fazendo com que essa disposição espelhada criasse uma relação de sentido onde o episódio da fundação vicentina passava a compor o processo de ocupação histórica do território, funcionando também como antessala da epopeia bandeirante.

Os documentos e cartas geográficas, bem como as inserções posteriores de objetos e retratos históricos na sala A-10 - como de Alexandre de Gusmão e de José Maria da Silva Paranhos, o barão do Rio Branco - permitem inferir, por fim, que esse processo de formação territorial havia sido realizado como conquista essencialmente diplomática, inaugurado pelo encontro pacífico entre portugueses e indígenas, tal qual sugestionava a tela de Benedito Calixto.

Afonso Taunay trabalhou nas duas décadas seguintes para a concretização da nova proposta museográfica para o Museu e, além de se ocupar com encomendas de pinturas e esculturas a artistas renomados da época ${ }^{46}$, solicitou que a pintura "Partida da Monção", enviada para o Li- ceu de Artes e Ofícios em 1905, retornasse para a sala A-9 do Monumento do Ipiranga ${ }^{47}$.

O diretor documentou o estágio final desse replanejamento no Guia da Secção Historica do Museu Paulista, oferecendo descrições sumarizadas dos objetos expostos em cada sala. Atendo-nos novamente à "Fundação de São Vicente", ali renomeada como "Desembarque de Martim Affonso em S. Vicente, em 1532", Taunay chama a atenção para sua popularidade, "pelas continuas reproducções que delles se fazem"48. Essa descrição não era um privilégio das pinturas de Calixto: outras pinturas históricas em grande formato, como a "Independência ou Morte!" , exibida no Salão de Honra, e "O Primeiro Desembarque de Pedro Álvares Cabral em Porto Seguro"50, na sala A-12, e "Fundação de São Paulo"51, na sala A-15, recebiam esse mesmo destaque em suas respectivas descrições.

Essa constatação nos direciona a um último esforço em compreender a potência da trajetória das apropriações da imagem da "Fundação de São Vicente". Para tanto, nos valeremos de dois exemplos que, por ora, nos pareceram os mais significativos.

O primeiro diz respeito aos livros escolares a partir de 1916, com a publicação de Minha Pátria por João Pinto e Silva ${ }^{52}$. Já nos anos seguintes, outras publicações também utilizaram a pintura de Calixto para ilustrar o episódio da fundação 


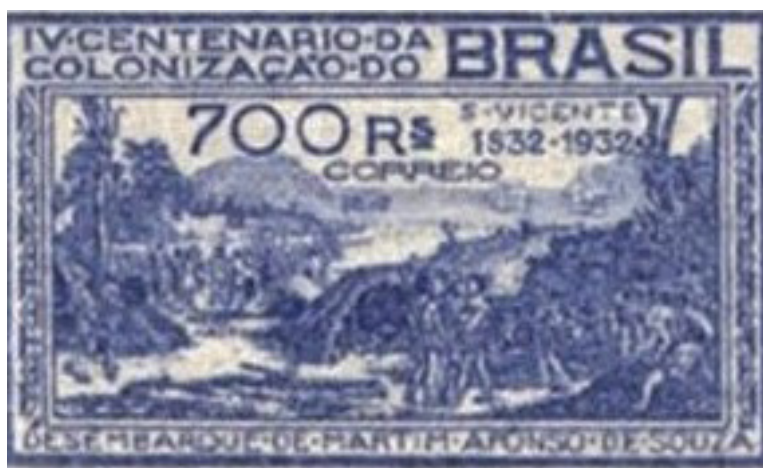

Figura 13. Selo de 700 réis. Coleção do autor.

53. Cf. POMBO, José Francisco da Rocha. História do Brazil com muitos mappas históricos e gravuras explicativas. São Paulo: Companhia Melhoramentos, 1918, p. 35; BRAGA, Creso. Breves Lições de História do Brasil. São Paulo: Typographia Piratininga, 1922, p. 25; História do Brasil para uso das aulas do curso preliminar. Coleção PPS. Sexta edição ilustrada. $35^{\circ}$ milheiro. Livraria Salesiana Editora: São Paulo, 1932, p. 23. Acervo LEMAD-DH/

54. Revista do Instituto tórico e Geográfico de São Paulo. Vol. XXIX. Conferencias commemorativas do IV Centenario da Fundação de São Vicente, 1532-1932. São Paulo, 1932, p. 261-265.

55. Série Comemorativa do IV Centenário da Colonização do Brasil. Edital de Selo 1932-001.4. Acervo do Museu Correios. Consultado em: 09 de outubro de 2017. vicentina em 1532: História do Brasil, de Rocha Pombo (1918), Breves Lições de História do Brasil, de Creso Braga (1922) e História do Brasil (1932) ${ }^{53}$, são exemplos meritórios de atenção por ajudarem a difundir e cristalizar essa pintura histórica como "visão oficial" de um dos principais episódios da história do Brasil. Seria impreterível, enfim, observar que, sendo o livro Minha Pátria uma exceção, os demais entraram em circulação após a inauguração da sala A-10 no Museu Paulista.

O segundo exemplo nos leva a 1932, quando foi comemorado o $4^{\circ}$ Centenário da Fundação de São Vicente. José Torres de Oliveira, o presidente do Instituto Histórico e Geográfico de São Paulo, assistido por outros membros proeminentes (inclusive Afonso Taunay), enviou uma petição para que o governo federal cunhasse moedas e imprimisse selos comemorativos. Tendo julgado a ocasião meritória, “(...) A fundação, em 1532, do município de S. Vicente", descreve o decreto, "(...) assinala o início da colonisação no Brasil”" sendo "(...) digna de especial comemoração"54.

Os selos comemorativos foram postos em circulação já durante o mês de junho de 1932, tendo valores de 20 até 700 réis e reproduziam o mapa da capitania de São Vicente, as efígies de João Ramalho, Tibiriçá; Martim Afonso de Souza, Dom João III e, o de 700 réis, uma versão adaptada da “(...) famosa tela do desembarque de Martim Afon- so de Souza, na baía de São Vicente, pintada pelo célebre brasileiro B. Calisto (...)"55. (Figura 13).

Esses dois exemplos lastreiam a popularidade mencionada por Taunay no Guia de 1937. Em nossa interpretação, esse selo comemorativo emitido pelo governo federal, em conjunto aos livros escolares, foram vetores cruciais para ampliar a circulação imagética da pintura e cristalizar seu potencial representativo simbólico para além dos liames local e regional, sendo necessário, até mesmo em função do ocaso perrepista com a revolução de 1930, requalificar e projetar seu potencial para o âmbito nacional.

Pode-se observar que há trajetórias distintas e concomitantes nas apropriações da imagem da obra ao longo das quatro primeiras décadas do século $X X$, fazendo com que ela transitasse pelas esferas local, regional e, por fim, nacional. Consolidado como o maior museu público de história, o Museu Paulista, por meio de seu acervo, foi um agente e um agenciador da difusão de uma consciência histórica formatada a partir da experiência de São Paulo no devir nacional.
No ano seguinte a publicação do Guia da Secção Histórica do Museu Paulista, o recém-fundado Serviço do Patrimônio Histórico e Artístico Nacional (SPHAN), então dirigido pelo advogado mineiro Rodrigo Melo Franco de Andrade (1898-1969), iniciou a formatação institucional de uma política 
de patrimonialização que, no caso do Estado de São Paulo, se voltou inicial e precisamente ao tombamento das coleções histórica, artística, arqueológica e etnográfica pertencentes ao Museu Paulista ${ }^{56}$.

De esforço das elites santista e vicentina em angariar projeção em uma São Paulo ainda frágil e recentemente republicana, a pintura "Fundação de São Vicente" é incorporada ao acervo do Museu Paulista e, por quase duas décadas, juntamente à "Independência ou Morte!", celebrava os episódios paulistas "fundacionais" da nação brasileira, na colônia e no Império; em 1917, Afonso Taunay reelaborou essa narrativa, atribuindo-Ihe uma nova camada semântica ao inseri-la em um arranjo expositivo que privilegiava todo o processo histórico-diplomático de formação do território brasileiro e em que atrelava a fundação da vila de São Vicente ao bandeirantismo.

Essas trajetórias distintas de apropriação permitem mapear as biografias dessa pintura: se no início do século XX ela servia de anteparo à propaganda dos projetos de modernização urbana perpetrados pelas elites das cidades sul- litorâneas e da capital, a partir da década de 1910, inserida na exposição de Afonso Taunay, foi incorporada como parte do repertório visual oficial e reproduzida em livros didáticos e em um dos selos comemorativos do quadricentenário da fundação de São Vicente - ou do "início da colonização brasileira".
Pertencendo ao acervo do Museu Paulista, a "Fundação de São Vicente" passa a fazer parte do corpus patrimonial nacional em 1938. Como vimos, sua imagem havia sido amplamente difundida ao longo das décadas anteriores, processo que homologou seu potencial enquanto lugar de memória.

O Museu Paulista inaugurava, em 23 de janeiro de 2007, a exposição "Imagens recriam a História", com curadoria de Paulo César Garcez Marins, que permaneceu em cartaz até 2013. Alinhada à pesquisa curatorial que intencionava compreender o papel das pinturas históricas na difusão e na criação do imaginário político sobre a história do Brasil, essa exposição foi um importante episódio da história institucional da "Fundação de São Vicente", iniciada, como vimos, em 1900.

Alocada na sala "Imaginar o Início" conjuntamente à "Fundação de São Paulo" e "O Primeiro Desembarque de Pedro Álvares Cabral em Porto Seguro", pinturas da autoria de Oscar Pereira da Silva, a "Fundação de São Vicente" foi problematizada como produção artística intencional a ser compreendida pelos esforços simbólicos da Primeira República em consolidar uma "visão oficial" do passado. A exposição, assim, mobilizava os dados até então conhecidos sobre os processos de sua criação e de sua incorporação ao acervo do Museu, finalizando com exemplos de sua reprodução em livros didáticos, entre outros suportes. 
É na esteira desse esforço em historicizar e sistematizar a circulação da tela de Calixto que, além de mapear e identificar as reproduções de sua imagem, procurou-se também estabelecer hipóteses sobre a historicidade e, sobretudo, a especificidade das apropriações analisadas, situando-as em relação aos interesses às quais respondiam.

Espera-se, com isso, contribuir para dimensionar os múltiplos alcances e forças das representações da história a partir da biografia da pintura musealizada, sendo um exercício profícuo, e também parte de um processo ainda em curso, que considera as dimensões de produção, circulação e consumo simbólico ao longo do século XX.

\section{Referências}

ALVES, Ana Maria de Alencar. O Ipiranga apropriado: ciência, política e poder. O Museu Paulista 1893-1922. São Paulo: Humanitas, EDUSP, 2001.

ALVES, Caleb Faria. Benedito Calixto e a construção do imaginário republicano. Bauru: EDUSC, 2003.

CAPELATO, Maria Helena Rolim e FERRETTI, Danilo José Zion. João Ramalho e as Origens da Nação: os paulistas na comemoração do IV centenário da descoberta do Brasil. Revista Tempo, v. 04, n. 08, 1999. Disponível em: http://www. historia.uff.br/tempo/artigos_dossie/artg8-4.pdf Acesso em 28 ago. 2019.

FERREIRA, Antônio Celso. A epopeia bandeirante: letrados, instituições, invenção histórica (1870-1940). São Paulo: Editora UNESP, 2002.

FERRETTI, Danilo José Zion. A Construção da Paulistanidade: identidade, historiografia e política em São Paulo (1856-1930). Tese (Doutorado em História Social) - Universidade de São Paulo, São Paulo, 2004.

FREHSE, Fraya. Cartões postais paulistanos da virada do século XX: Problematizando a São Paulo "moderna". Horizontes Antropológicos, ano 06, n. 13, p. 127-153, jun. 2000. Disponível em: http://www.scielo.br/scielo.php?script=sci_artte $x t \& p i d=\$ 0104-71832000000100007$ Acesso em 15 ago. 2019.

GERODETTI, João Emílio e CORNEJO, Carlos. Lembranças de São Paulo. O litoral paulista nos cartões-postais e álbuns de lembranças. São Paulo: Solaris Edições Culturais, 2001.

IHERING, Rodolpho von. Guia pelas Collecções do Museu Paulista. São Paulo: Typographia Cardozo Filho, 1907.

KOSSOY, Boris. (ed.) Dicionário Histórico-Fotográfico Brasileiro. Fotógrafos e ofício da fotografia no Brasil (1833-1910). São Paulo: Instituto Moreira Salles, 2002. 
MARINS, Paulo César Garcez. Nas matas com poses de reis: a representação de bandeirantes e a tradição da retratística monárquica europeia. Revista do IEB, n. 44, p. 77-104, fev. 2007. Disponível em: http://www.revistas.usp.br/rieb/article/view/34563/37301. Acesso em: 12 ago. 2019

MENESES, Ulpiano Toledo Bezerra de. Benedito Calixto como documento: sugestões para uma releitura histórica. IN: OLIVEIRA, Maria Alice Milliet. (org.). Benedito Calixto: memória paulista. São Paulo: Banespa/Pinacoteca do Estado, 1990, p. 25-36.

MENESES, Ulpiano Toledo Bezerra. Fontes visuais, cultura visual, história visual. Balanço provisório, propostas cautelares. Revista Brasileira de História, v. 23, n 45, p. 11-36, 2003. Disponível em: http://www.scielo.br/pdf/rbh/ v23n45/16519.pdf. Acesso em 26 ago. 2019.
MONTEIRO, Michelli Cristine Scapol. Fundação de São Paulo, de Oscar Pereira da Silva: trajetórias de uma imagem urbana. Dissertação (Mestrado em Arquitetura e Urbanismo) - Faculdade de Arquitetura e Urbanismo, Universidade de São Paulo, São Paulo, 2012.

OLIVEIRA, Cecília Helena de Salles (org.). O Museu Paulista e a gestão de Afonso Taunay: Escrita da História e Historiografia, séculos XIX e XX. São Paulo: Museu Paulista da USP, 2017.

NEVES, Cylaine Maria. A Vila de São Paulo de Piratininga. Fundação e Representação. São Paulo: Annablume; FAPESP, 2007;

TAUNAY, Afonso Teixeira d'Escragnolle. Guia da Seção de História do Museu Paulista. Imprensa Oficial do Estado de São Paulo: São Paulo, 1937. THUILLIER, Jacques. Le problème des « grands formats ". Revue de l'Art, n. 102, p. 0510, 1993. Disponível em: www.persee.fr/doc/ rvart_0035-1326_1993_num_102_1_348070. Acesso em 20 ago. 2019. 